ISSN $2623-6575$

GLASILO

FUTURE

UDK 60

UDK 631

UDK 630

UDK 336

UDK 338

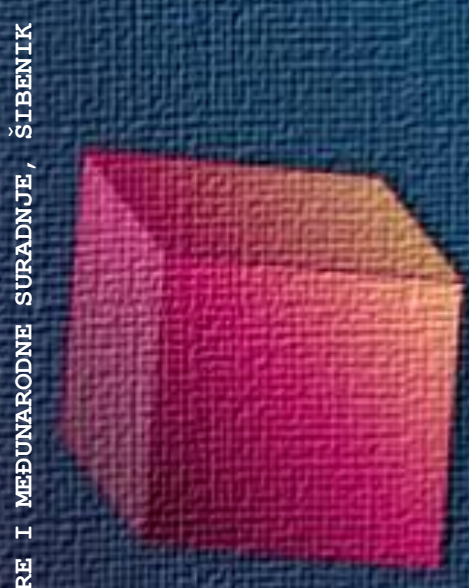

5
5
5

î

s.

䐱

5
5
0
0
0
0
0

A

8

S

竞

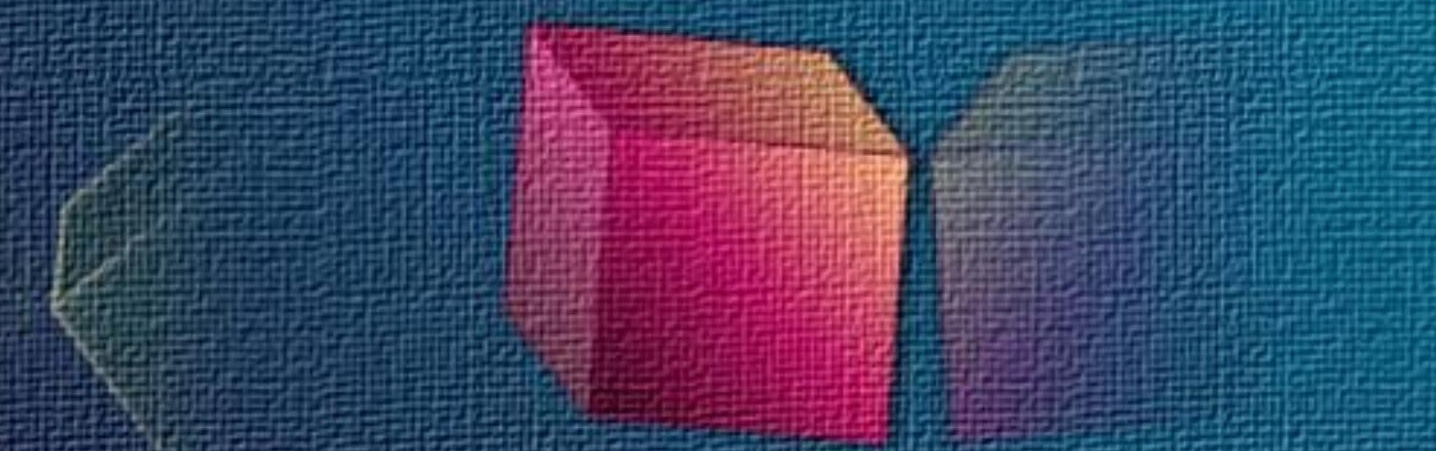

(1) 


\section{Glasilo Future}

\section{Stručno-znanstveni časopis}

Nakladnik: FUTURA

\section{FUTUR}

Sjedište udruge: Šibenik

\section{Adresa uredništva:}

Bana Josipa Jelačića 13 a, 22000 Šibenik, Hrvatska / Croatia 留 / 圆: +385 (0) 022218133

$\triangle$ : urednistvo@gazette-future.eu / editors@gazette-future.eu (3): www.gazette-future.eu

\section{Uređivački odbor / Editorial Board:}

Doc. dr. sc. Boris Dorbić, v. pred. - glavni i odgovorni urednik / Editor-in-Chief

Emilija Friganović, dipl. ing. preh. teh., v. pred. - zamjenica g. i o. urednika / Deputy Editor-in-Chief

Ančica Sečan Matijaščić, mag. act. soc. - tehnička urednica / Technical Editor

Antonia Dorbić, mag. art. - zamjenica tehničke urednice / Deputy Technical Editor

Prof. dr. sc. Željko Španjol

Mr. sc. Milivoj Blažević

Vesna Štibrić, dipl. ing. preh. teh.

\section{Međunarodno uredništvo / International Editorial Board:}

Prof. dr. sc. Kiril Bahcevandziev - Portugal (Instituto Politécnico de Coimbra)

Prof. dr. sc. Martin Bobinac - Srbija (Šumarski fakultet Beograd)

Doc. dr. sc. Zvezda Bogevska - Makedonija (Fakultet za zemjodelski nauki i hrana Skopje)

Dario Bognolo, mag. ing. - Hrvatska (Veleučilište u Rijeci)

Prof. dr. sc. Agata Cieszewska - Poljska (Szkoła Główna Gospodarstwa Wiejskiego w Warszawie)

Dr. sc. Bogdan Cvjetković, prof. emeritus - Hrvatska (Agronomski fakultet Zagreb)

Prof. dr. sc. Duška Ćurić - Hrvatska (Prehrambeno-biotehnološki fakultet Zagreb)

Doc. dr. sc. Margarita Davitkovska - Makedonija (Fakultet za zemjodelski nauki i hrana Skopje)

Doc. dr. sc. Dubravka Dujmović Purgar - Hrvatska (Agronomski fakultet Zagreb)

Prof. dr. sc. Semina Hadžiabulić - Bosna i Hercegovina (Agromediteranski fakultet Mostar)

Prof. dr. sc. Péter Honfi - Mađarska (Faculty of Horticultural Science Budapest)

Prof. dr. sc. Valeria Ivanova - Bugarska (Fakultet za lozaro-gradinarstvo Plovdiv)

Doc. dr. sc. Orhan Jašić - Bosna i Hercegovina (Filozofski fakultet Tuzla)

Prof. dr. sc. Tajana Krička - Hrvatska (Agronomski fakultet Zagreb)

Prof. dr. sc. Biljana Lazović - Crna Gora (Biotehnički fakultet Podgorica)

Prof. dr. sc. Bosiljka Mustać - Hrvatska (Sveučilište u Zadru)

Hrv. akademik prof. dr. sc. Stanislav Nakić - Bosna i Hercegovina (Sveučilište Hercegovina Mostar)

Sandra Popović, mag. ing. - Srbija (Poljoprivredni fakultet Beograd)

Doc. dr. sc. Bojan Simovski - Makedonija (Šumarski fakultet Skopje)

Prof. dr. sc. Davor Skejić - Hrvatska (Građevinski fakultet Zagreb)

Doc. dr. sc. Milan Stanković - Srbija (Univerzitet u Kragujevcu)

Akademik prof. dr. sc. Refik Šećibović - Bosna i Hercegovina (Visoka škola za turizam i menadžment Konjic)

Prof. dr. sc. Andrej Šušek - Slovenija (Fakulteta za kmetijstvo in biosistemske vede Maribor)

Prof. dr. sc. Elma Temim - Bosna i Hercegovina (Agromediteranski fakultet Mostar)

Doc. dr. sc. Ivana Vitasović Kosić - Hrvatska (Agronomski fakultet Zagreb)

Doc. dr. sc. Ana Vujošević - Srbija (Poljoprivredni fakultet Beograd)

Prof. dr. sc. Vesna Židovec - Hrvatska (Agronomski fakultet Zagreb)

Lektura i grafička priprema: Ančica Sečan Matijaščić, mag. act. soc.

Objavljeno: 31. prosinca 2018. godine.

Časopis izlazi u elektroničkom izdanju dva puta godišnje, krajem lipnja i prosinca, a predviđena su i dva interdisciplinarna specijalna izdanja tijekom godine iz STEM i ostalih znanstvenih/umjetničkih područja.

Časopis je besplatan. Rukopisi i recenzije se ne vraćaju i ne honoriraju.

Umnožavanje (reproduciranje), stavljanje u promet (distribuiranje), priopćavanje javnosti, stavljanje na raspolaganje javnosti odnosno prerada u bilo kojem obliku nije dopuštena bez pismenog dopuštenja Nakladnika. Sadržaj objavljen u Glasilu Future može se slobodno koristiti u osobne i obrazovne svrhe uz obvezno navođenje izvora. 


\section{Glasilo Future}

\section{Stručno-znanstveni časopis}

FUTURA - stručno-znanstvena udruga za promicanje održivog razvoja, kulture i međunarodne suradnje, Bana Josipa Jelačića 13 a, 22000 Šibenik, Hrvatska

(2018) 1 (4) 01-54

\section{SADRŽAJ:}

Izvorni znanstveni rad (original scientific paper)

Str.

B. Dorbić, Sandra Dukić, Emilija Friganović, Margarita Davitkovska,Zvezda Bogevska, Ana Vujošević, Sandra Popović

Percepcije i stavovi o ukrasnim karakteristikama i primjeni submediteranskog

listopadnog drveća u zimskom razdoblju

Perceptions and attitudes about ornamental characteristics of sub-mediterranean

deciduous trees during the winter season

\section{Stručni rad (professional paper)}

\section{Z. Maričić, L. Maričić}

Optimiziranje portfelja s različitim brojem imovine i različitim preferencijama rizika Portfolio optimization with different number of assets and different risk preferences

L. Maričić, Z. Maričić

Utjecaj dodatnih dionica na granice efikasnosti, portfelj s minimalnom varijancom i tangencijalni portfelj

Influence of additional shares on efficiency frontier, minimum variance portfolio and tangential portfolio

\section{Nekategorizirani rad (uncategorised paper)}

\section{B. Dorbić}

Prikaz knjige

Book review

\section{B. Dorbić}

Društvene vijesti

Social news 


\title{
Optimiziranje portfelja s različitim brojem imovine i različitim preferencijama rizika
}

\section{Portfolio optimization with different number of assets and different risk preferences}

\author{
Zoran Maričićc ${ }^{*}$, Luka Maričić
}

stručni rad (professional paper)

doi: $10.32779 / g f .1 .4 .2$

\section{Sažetak}

U ovome radu korištena je suvremena teorija portfelja Harryja Markowitza za stvaranje efikasnih portfelja unaprijed odabranih dionica. Izabrali smo četiri dionice sa Zagrebačke burze iz turističkog sektora. U prvom koraku iz povijesnih podataka kroz pet godina a preko dnevnih prinosa izračunavaju se očekivani povrat, varijanca i standardna devijacija za svaku pojedinu dionicu. Nakon toga izračunava se granica efikasnosti [Efficient frontier (eng.)], kao portfelj od ove četiri dionice koji daje najbolji odnos prinosa i rizika. Svrha je pokazati kako najbolje kombinirati ulaganja u ove četiri dionice da bi dobili najbolji odnos prinosa i rizika. Rezultati rada jasno pokazuju da ima smisla ulagati u učinkoviti portfelj. Razlog tomu je da ovakva diversifikacija, u usporedbi s ulaganjem u pojedinačnu dionicu, ili povećava prinos uz dani rizik ili smanjuje volatilnost uz dani prinos. Osim toga, treba naglasiti da je ulaganje $u$ jedan učinkoviti portfelj $s$ vise dionica poželjnije od ulaganja $u$ jedan učinkovit portfelj s manje dionica.

Ključne riječi: efikasna granica, portfelj, diversifikacija, dionice, investicijske odluke.

\begin{abstract}
In this paper, Modern portfolio theory of Harry Markowitz was used to build-up efficient portfolios of forehand chosen stocks. Four tourism sector stocks were chosen from Zagreb Stock Exchange. In the first step, on the basis of historic daily returns in five years period, expected return, variance and standard deviation for each chosen stock were calculated. Afterward, Efficient frontier of four stocks with best return and risk profile was calculated. The task is to show the optimal combination of four stocks investment that produces the best risk return profile. The results of the paper clearly show that it makes sense to invest in an efficient portfolio. The reason for this is that such diversification, as compared to single stock investment, either increases return with a given risk or decreases volatility with a given return. Besides, it should be emphasized that investment in an efficient portfolio with
\end{abstract}

\footnotetext{
${ }^{1}$ Veleučilište "Marko Marulić" u Kninu, Krešimirova 30, 22300 Knin, Republika Hrvatska.

* Zoran Maričić, MBA, e-mail: zmaricic@veleknin.hr

${ }^{2}$ Wirtschaftsuniversität Wien, Welthandelsplatz 1, 1020 Wien, Republika Austria.
} 
more stocks is preferable to investment in an efficient portfolio with fewer stocks.

Key words: efficient frontier, portfolio, diversification, stocks, investment decisions.

\section{Uvod}

Investitor koji želi zaraditi ulaganjem na tržištu dionica ima mogućnost uložiti u pojedinu dionicu ili grupu njih (portfelj). Svrha je postići najveći mogući prinos uz najmanji rizik, no problem je što su obje varijable pozitivno korelirane tj, želeći veće prinose moramo prihvatiti i veće rizike. Poznati rad H. Markowitza (1952) pokazao je da izgradnjom efikasnih portfelja možemo postići najveći mogući prinos uz najniži mogući rizik. Očekivani prinosi mogu se povećati kupnjom rizičnijih dionica, dok se rizik može smanjiti kupnjom manje rizičnih dionica, no kako smanjiti rizik, a da to ne šteti prinosu?

Zadatak se može riješiti korištenjem takozvane "moderne teorije portfelja". Ovu teorija je prvi put javno predstavio 1952. godine u "Journal of Finance" američki ekonomist Harry Markowitz (1952). Ona predstavlja temelj suvremenog pristupa ulaganju i pokazuje međuovisnost prinosa i rizika.

Racionalni investitori na razumno učinkovitim tržištima kapitala mogu procijeniti moguću profitabilnost pojedinih investicija statističkim ponderiranjem njihovih očekivanih prinosa, temeljenu na normalnoj distribuciji.

- Investitori neskloni riziku očekuju ili maksimalne prinose za dani nivo rizika ili dani prinos za minimalni rizik.

- Rizik je mjeren standardnom devijacijom prinosa, a ukupni očekivani prinos je mjeren svojom vjerojatnom ponderiranom sredinom.

Koristeći kriterij prinos-varijanca, ulagači tada imaju tri opcije kada stvaraju portfelj investicija ovisno o karakteristikama svake pojedine investicije iz portfelja:

- Trgovati (kupiti ili prodati).

- Zadržati (ne činiti ništa).

- Mijenjati (npr. dionice za neke druge vrijednosne papire) (Ross et al., 1998; Hirt et al., 2008; Welch, 2011).

Prvo, što je to rizik? Rizik je mogućnost da stvarni povrat ulaganja odstupa od očekivanog povrata. Rizik je predstavljen varijancom odnosno standardnom devijacijom.

Trenutno je ovo najčešće korištena metoda za procjenu je li investicija dobra ili loša. Temelji se na teoriji o savršenom tržištu kapitala i racionalnosti i nesklonosti riziku ulagača. Znači, ulagači ne vole rizik te su stoga voljni prihvatiti veći rizik samo ako dobiju mogućnost za veći prinos zauzvrat. 
Očekivani prinos portfelja je vagani prosjek svih pojedinačnih prinosa dionica u portfelju. Rizik portfelja ovisi o varijancama pojedinačnih dionica, ali i kovarijancama (korelacijama) među njima. Beta koeficijent kao mjera rizika je druga normalizacija kovarijance i govori o snazi utjecaja jedne dionice na drugu. To je nagib regresijskog pravca koji najbolje odgovara prinosima dviju dionica.

Ova metoda omogućuje izračun portfelja s maksimalnim prinosom za određenu razinu rizika ili portfelja s minimalnom varijancom za određenu razinu očekivanog prinosa (Luenberger, 1998; Welch, 2008).

\section{Materijali i metode}

\section{Zadatak}

Za ovaj rad su izabrane dionice kako slijedi:

- Valamar Riviera (RIVP)

Valamar Riviera je jedno od najvećih hrvatskih turističkih poduzeća. Sjedište mu je u Poreču.

- Arena Hospitality Group (ARNT)

Arena Hospitality Group jedna je od glavnih hotelskih grupacija u Srednjoj i Istočnoj Europi. Sjedište joj je u Puli.

- Adris Grupa (ADRS)

Adris grupa jedna je od vodećih hrvatskih i regionalnih kompanija. Bavi se raznim djelatnostima, ali fokus joj leži na turizmu. Sjedište joj je u Rovinju.

\section{- $\quad$ Liburnia Riviera Hoteli (LRH)}

Liburnia Riviera Hoteli je jedna od vodećih turističkih kompanija u regiji. Sjedište joj je u Opatiji.

Razlog odabira ovih dionica leži u činjenici da su to sve velike hrvatske kompanije kojima se trguje na Zagrebačkoj burzi, a svima su cijene u kunama što znači da ne treba voditi računa oko promjene valutnih tečajeva.

Dionice su iz turističkog sektora, što demonstrira diversifikaciju unutar jednog sektora. Treba uzeti u obzir da je uzet relativno mali period trgovanja dionicama te da je ovo period kada se još jako na hrvatskom tržištu kapitala osjećala financijska kriza. Broj dana trgovanja po dionicama za navedeni period je različit i prikazan je u Tablici 1. Broj dana je izračunat na bazi prikaza Zagrebačke burze kroz promatrani period od 01. 01. 2012. do 31. 12. 2016. 
Tablica 1. Broj dana trgovanja po dionicama za navedeni period (Zagrebačka burza, 2017).

Table 1. Number of trading days per share for the specified period (Zagreb Stock Exchange, 2017).

\begin{tabular}{|l|c|c|c|c|}
\hline Naziv dionice & RIVP & ARNT & ADRS & LRH \\
\hline Broj radnih dana & 1107 & 1090 & 916 & 759 \\
\hline
\end{tabular}

U izračunima korištenjem povijesnih podataka polazimo od pretpostavke da nam ovi podatci određuju i buduće varijable kao što su: aritmetička sredina, varijanca, kovarijanca, beta i dr.

Uz ovo pretpostavljamo da podatci slijede "slučajni hod" tj. na osnovu prošlih prinosa ne možemo ništa reći o budućim.

Mi smo također pretpostavili da su investitori racionalni te da su tržišta kapitala razumno učinkovita u procesuiranju informacija. Stoga što je današnja cijena neovisna od jučerašnje, učinkovita tržišta ne djeluju "po sjećanju" i kretanje pojedinačnih cijena dionica je "slučajno". Isto tako, investitori koji su uključeni na tržištu su toliko brojni da niti jedan nema komparativnu prednost. Kratkoročno gledajući "nešto dobiješ, nešto izgubiš", ali u dugoročnom pogledu, investiranje je fer igra za sve sudionike.

\section{Istraživačka pitanja}

Ove informacije su baza za odgovaranje na pitanja koja slijede.

Kakvu strukturu rizik-prinos imaju pojedinačne dionice?

Može li se pretpostaviti da su prinosi normalno distribuirani?

Koje komponente doprinose posebno puno poboljšanju strukture rizik-prinos portfelja?

Koji portfelj sastavljen od četiri dionice ima minimalni rizik?

Kako se mijenjaju omjeri u portfelju pri različitim preferencijama rizika?

\section{Pretpostavke}

Rad je baziran na sljedećim pretpostavkama:

- nema bezrizične stope prinosa;

- nema transakcijskih troškova;

- nema kratke prodaje [short-selling (eng.)];

- nema poreza ni naknada

Promatrani period je 5 godina, od 01. 01. 2012. do 31. 12. 2016. u kojem se trgovalo dionicama korištenih poduzeća.

Korišteni podatci su dnevni prinosi.

Sve jedinice u računanjima (prinosi, varijance, standardne devijacije, kovarijance) su prikazane anualizirane. 


\section{Okvir}

Najprije su dane formule i kratki opis najčešće korištenih varijabli pri vrednovanju vrijednosnica i portfelja (Berk i DeMarzo, 2016).

\section{Očekivani prinos}

Očekivani prinos portfelja je vagani prosjek očekivanih prinosa pojedinačnih dionica. Drugim riječima, utjecaj jedne dionice ovisi o njenom udjelu u portfelju.

$\mathrm{Rp}=\sum_{\mathrm{i}=1}^{\mathrm{N}} \mathrm{Xi} * \mathrm{Ri}$

sa:

$\mathrm{R} p \quad$ očekivani prinos portfelja

$\mathrm{X} i \quad$ udio (ponder) dionice $i$

$\mathrm{R} i \quad$ očekivani prinos dionice $i$

Udio dionice $i$ u portfelju je udio ukupne vrijednosti portfelja koji je investiran u tu dionicu (npr. ako se posjeduje dionica i u vrijednosti 200.000,00 kuna, unutar portfelja vrijednog 1.000.000,00 kuna, onda je udjel (ponder) te dionice i $200000 / 1000000=20 \%$ ).

Prinos dionice $i$ je broj koji pokazuje kako se vrijednost dionice promijenila u jednom periodu. Formula za izračun je:

$\mathrm{R}_{\mathrm{i}}=\frac{\mathrm{P}_{\mathrm{t}}-\mathrm{P}_{\mathrm{t}-1}}{\mathrm{P}_{\mathrm{t}-1}}$

sa:

$\mathrm{R} i \quad$ prinos dionice $i$

Pt cijena dionice $i$ na kraju perioda

$\mathrm{P} t-1 \quad$ cijena dionice $i$ na početku perioda

\section{Standardna devijacija}

Standardna devijacija je mjera disperzije jednog skupa podataka od svoje srednje vrijednosti (Bodie et al., 2006). Što su dalje pojedini podatci od srednje vrijednosti, to je veća devijacija. Koristi se kao standardna mjera rizika ulaganja. 
Standardna devijacija izračunava se kao kvadratni korijen varijance.

$\operatorname{Std}(R)=\sqrt{\operatorname{Var}(R)}$

sa:

$\mathrm{R} \quad$ prinos portfelja

$\operatorname{Std}(\mathrm{R})$ standardna devijacija prinosa portfelja $\mathrm{R}$

$\operatorname{Var}(\mathrm{R})$ varijanca prinosa portfelja $\mathrm{R}$

Varijanca se računa kao kvadratno odstupanje prinosa portfelja i njegove očekivane vrijednosti.

$\operatorname{Var}(\mathbf{R})=\mathbf{E}\left[(\mathbf{R}-\mathbf{E}[\mathbf{R}])^{2}\right]$

sa:

$\mathrm{R} \quad$ prinos portfelja

$\operatorname{Var}(\mathrm{R})$ varijanca prinosa $\mathrm{R}$

$\mathrm{E}[\mathrm{R}] \quad$ očekivana vrijednost od $\mathrm{R}$

\section{Kovarijanca}

Kovarijanca je još jedna nužna vrijednost za analizu portfelja. Mjeri zajedničku varijabilnost prinosa dviju dionica. Kod portfelja s velikim brojem dionica utjecaj kovarijanci daleko nadilazi utjecaj standardnih dionica. Ako u portfelju imamo 10 dionica onda u njemu postoji 10 varijanci i $\mathrm{N} \mathrm{x}(\mathrm{N}-1)$ kovarijanci tj, 90. Kovarijanca između prinosa $\mathrm{Ri}$ i Rj izračunava se produktom izraza koji se sastoje od očekivanih vrijednosti obaju prinosa. Ona pokazuje predznak tj, da li je odnos pozitivan ili negativan no njenu veličinu je teško interpretirati upravo kao i veličinu varijance.

$\operatorname{Cov}(\mathbf{R i}, \mathbf{R} \mathbf{j})=\mathbf{E}[(\mathbf{R i}-\mathbf{E}[\mathbf{R i}]) *(\mathbf{R j}-\mathbf{E}[\mathbf{R j}])$

sa:

$\mathrm{Ri} \quad$ prinos dionice $\mathrm{i}$

$\mathrm{Rj} \quad$ prinos dionice $\mathrm{j}$

$\mathrm{E}[\mathrm{Ri}]$ očekivana vrijednost od Ri

$\mathrm{E}[\mathrm{Rj}]$ očekivana vrijednost od $\mathrm{Rj}$

\section{Koeficijent korelacije}

Da bi bolje razumjeli snagu veze između prinosa dionica imamo korelaciju. To je prva normalizacija kovarijance. Kreće se od -1 do +1 . i pokazuje pouzdanost odnosa između prinosa. 
$\operatorname{korelacija~}(i, j)=\frac{\operatorname{cov}(i, j)}{\operatorname{sd}(i) \times s d(j)}$

Korelacija od +1 je savršeno pozitivna a od -1 savršeno negativna. Uvijek kad je korelacija manja od +1 diversifikacija se isplati a najveća je kad postoji savršeno negativna korelacija.

\section{Beta koeficijent}

Beta koeficijent $(\square)$ portfelja je vagana sredina beta koeficijenata dionica od kojih se sastoji. Dakle, utjecaj jedne dionice ovisi o njenom udjelu u portfelju. On pokazuje doprinos rizika pojedine dionice riziku portfelja.

$\operatorname{beta}(p)=\sum_{i=1}^{N} X i * \operatorname{beta}(i)$

Beta koeficijent je nagib regresijskog pravca između prinosa portfelja i dionice $\mathrm{i}$ izračunava se formulom.

$\operatorname{beta}(i, j)=\frac{\operatorname{cov}(i, j)}{\operatorname{Var}_{(j)}}$

Ovaj koeficijent govori o snazi utjecaja pojedine dionice tj, da li na npr. dionica A ima veći utjecaj na dionicu B ili C.

\section{Diversifikacija}

Racionalni, riziku neskloni investitor ne voli rizik. Imajući na raspolaganju određenu količinu novca, možemo investirati u jednu od naših dionica ili u više njih. Investirajući u jednu dionicu naša zarada, ali i rizik ovise samo o toj dionici no investirajući dio novca u svaku od dionica možemo postići smanjenje rizika (standardne devijacije) uz istovremeno zadržavanje određenog očekivanog prinosa. Ovo je glavni uvid "moderne teorije portfelja" koja traži da se provede diversifikacija, a to znači ulaganje u više vrijednosnica.

Diversifikacija je strategija ulaganja za racionalne i riziku nesklone investitore kroz ulaganja u više vrijednosnica (portfelj). Ovim se smanjuje izloženost riziku karakterističnom za pojedinu tvrtku (dionicu) što rezultira smanjenjem volatilnosti portfelja. Ovaj rizik naziva se nesistematski ili jedinstveni rizik dionice.

Nasuprot ovomu, tržišni ili sistematski rizik ne može biti diversificiran (Bodie et al., 2006). On dolazi od izvora rizika koji utječu na cijelu ekonomiju te pošto se ne može izbjeći mora biti naplaćen. Razlika između rizika specifičnog za određenu tvrtku i tržišnog rizika jedna je od najvažnijih spoznaja u području financija i izvor nastanka CAPM modela, modela vrednovanja imovine na tržištu kapitala. 
Investitori mogu očekivati da će biti nagrađeni za poduzimanje tržišnog rizika no ne i za nesistematski, jedinstveni rizik. Jedinica sistematskog rizika je beta koeficijent. Od ukupnog rizika mjerenog standardnom devijacijom na razvijenim financijskim tržištima oko $75 \%$ rizika se može odbaciti diversifikacijom, a preostalih $25 \%$ je sistematski rizik.

\section{Granica efikasnosti}

Ulažući različite udjele (pondere) u više dionica dobivamo portfelje s različitim očekivanim prinosima i standardnim devijacijama. No koja je najbolja kombinacija udjela u portfelju? Granica efikasnosti (učinkovitosti) odgovara na pitanje kako postići optimalnu diversifikaciju. Ona je krivulja na grafikonu (Slika 1). koja prikazuje odnos između očekivanog prinosa i rizika za niz portfelja.

Da bi portfelj bio na granici učinkovitosti, mora imati maksimalni očekivani prinos za određenu razinu rizika (Ross at al., 1998).



Slika 1. Granica učinkovitosti (Welch, 2008).

Figure 1. Efficient frontier (Welch, 2008).

Efikasni portfelji su oni koji se nalaze na granici učinkovitosti. Na ovoj granici ako želimo povećati prinos portfelja moramo prihvatiti i povećani rizik i krećemo se prema desnom gornjem uglu. Kod tzv. "neučinkovitih portfelja" povećavajući rizik (standardnu devijaciju) ne dobivamo povećanje očekivanog prinosa nego smanjenje (Welch, 2008). 


\section{Rezultati istraživanja}

\section{Individualne dionice}

Sad za pojedine dionice izračunavamo prinos i standardnu devijaciju na bazi povijesnih podataka koristeći ugrađene Excel formule. Izračun ovih varijabli moguć je i preko prikazanih formula, ali je naporniji. Prinosi dionica su dnevni te smo izvršili anualizaciju. Ovi podatci su prikazani u Tablici 2 i grafu (Slika 2).

Tablica 2. Anualizirani prinosi i standardne devijacije za odabrane dionice.

Table 2. Annualized returns and standard deviations for selected shares.

\begin{tabular}{|l|c|c|}
\hline & Prinos & Standardna devijacija \\
\hline RIVP & $44,90 \%$ & $69,31 \%$ \\
\hline ARNT & $56,64 \%$ & $47,00 \%$ \\
\hline ADRS & $36,90 \%$ & $31,89 \%$ \\
\hline LRH & $27,02 \%$ & $52,21 \%$ \\
\hline
\end{tabular}

Iz grafa (Slika 2). vidljivo je da ARNT ima najveći očekivani prinos, a LPH najmanji, RIVP ima najveću volatilnost, a ADRS najmanju.

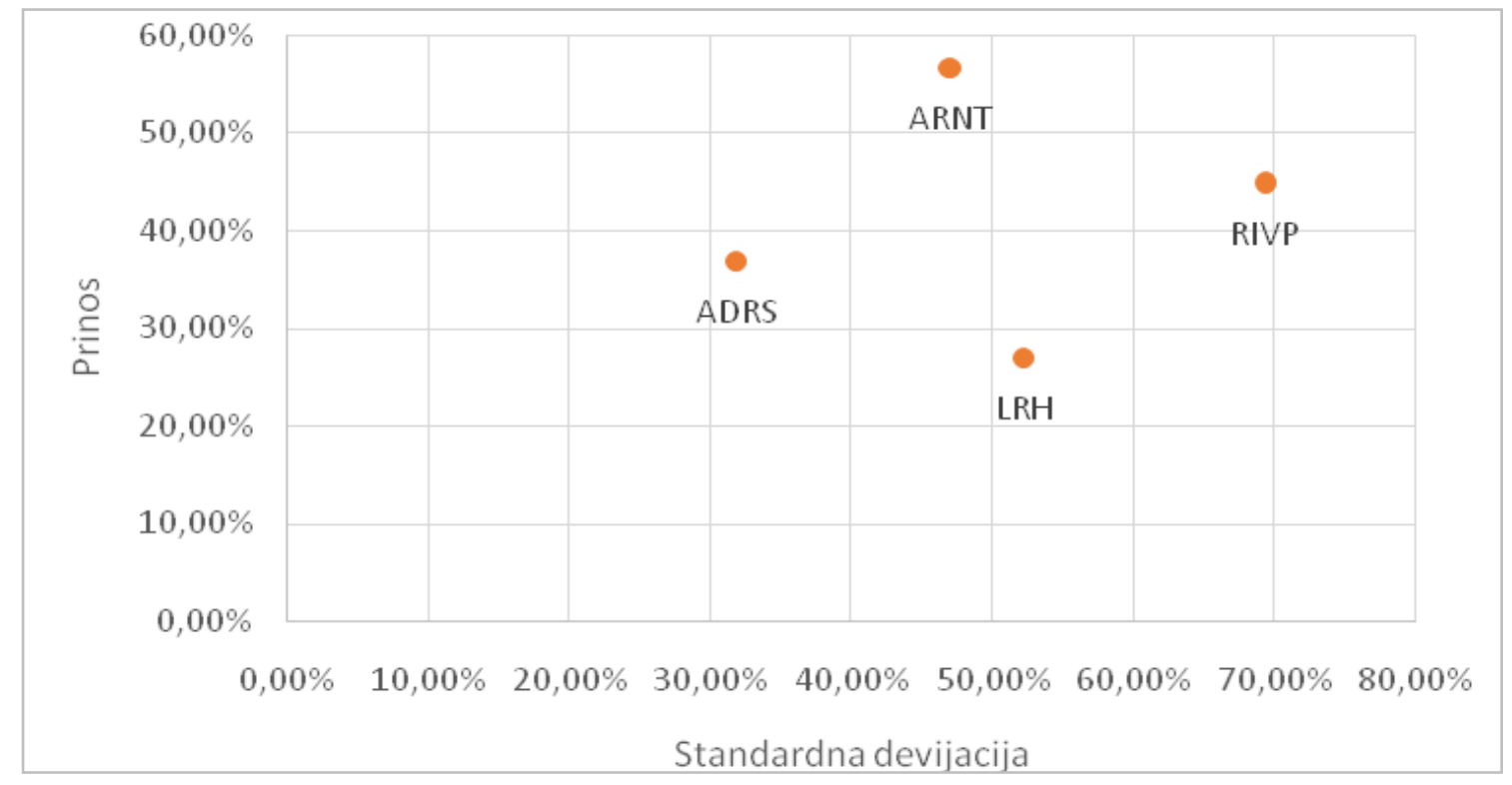

Slika 2. Grafički prokaz odnoss rizika i prinosa pojedinačnih dionica.

Figure 2. Graph-Risk and return trade-offs for specified shares.

Brojne su kombinacije ulaganja u portfelje od dvije, tri ili četiri dionice.

Iako neke dionice mogu izgledati loše one nude mogućnost diversifikacije u efikasnom portfelju.

Mi ćemo se baviti samo s portfeljem od četiri dionice, odnosno najboljom kombinacijom udjela 
investiranih u pojedine dionice. No, prije dogovora na ovo pitanje moramo provjeriti neke pretpostavke na kojima počiva suvremena teorija portfelja.

Prvo pitanje je jesu li prinosi dionica normalno distribuirani. Da bi se to otkrilo potrebno je provesti statističko ispitivanje. Odabran je Jarque-Bera test (Luenberg, 1998). Ovo je statističko ispitivanje temeljeno na nakrivljenosti i kurtosisu. Na temelju tih izračuna može se provjeriti jesu li podatci (u ovom slučaju prinosi) normalno distribuirani.

U Tablici 3. prikazani su rezultati provedenih statističkih testova.

Tablica 3. Rezultati statističkih testova za sve dionice.

Table 3. Statistic test results for all shares.

\begin{tabular}{|l|r|r|r|r|c|}
\hline & \multicolumn{1}{|c|}{ Nakrivljenost } & \multicolumn{1}{c|}{ Kurtosis } & \multicolumn{1}{|c|}{ Jarque-Bera } & Jarque-Bera & P-vrijednost \\
\hline RIVP & $-1,35907856$ & 301,850717 & 22780,3109 & 4202967,36 & $0,00 \%$ \\
\hline ARNT & 1,39078668 & 11,2055673 & 33,3254721 & 6054,23852 & $0,00 \%$ \\
\hline ADRS & 4,101575963 & 44,6061648 & 514,250409 & 78510,61 & $0,00 \%$ \\
\hline LRH & 0,505055169 & 5,0307298 & 6,5821413 & 832,640875 & $0,00 \%$ \\
\hline
\end{tabular}

Nakrivljenost [skewness (eng.)] je mjera asimetrije distribucije vjerojatnosti slučajne varijable oko sredine. Ona pokazuje u kojem pravcu i veličini distribucija odstupa od normalne distribucije (Luenberg, 1998).

Kurtosis je mjera "repatosti" distribucije vjerojatnosti slučajne varijable. Ovo znači da je vjerojatnost ekstremnih rezultata, naročito negativnih, puno veća nego što sugerira normalna distribucija (Luenberg, 1998).

Jarque-Bera test je ocjena prilagodbe da li podatci iz uzorka imaju nakrivljenost ili kurtosis koja odgovara normalnoj distribuciji.

P-vrijednost svih dionica je vrijednost ispod razine signifikantnosti od 0,05 .

Zbog ovog gore navedenog odbacujemo hipotezu da su prinosi normalno distribuirani.

\section{Portfelj dionica}

Da bi se napravio portfelj od naše četiri dionice, potrebni su, osim očekivanih prinosa i standardnih devijacija pojedinačnih dionica, također i kovarijance ili korelacije između pojedinačnih dionica. Sve varijable izračunate su pomoću M. S. Excel 2013 formula (Tablice 4. i 5.). 
Tablica 4. Korelacije svih parova dionica.

Table 4. Correlations of all pairs of shares.

\begin{tabular}{|c|c|c|c|c|}
\hline & RIVP & ARNT & ADRS & LRH \\
\hline \begin{tabular}{|l|} 
RIVP \\
\end{tabular} & 1 & 0,0054550 & $-0,0349514$ & 0,0000303 \\
\hline \begin{tabular}{|l} 
ARNT \\
\end{tabular} & & 1 & 0,0563724 & 0,0476894 \\
\hline \begin{tabular}{|l} 
ADRS \\
\end{tabular} & & & 1 & 0,0621597 \\
\hline LRH & & & & 1 \\
\hline
\end{tabular}

Tablica 5. Kovarijance svih parova dionica.

Table 5. Covariances of all pairs of shares.

\begin{tabular}{|l|l|l|r|c|}
\hline & \multicolumn{1}{|c|}{ RIVP } & \multicolumn{1}{c|}{ ARNT } & \multicolumn{1}{c|}{ ADRS } & \multicolumn{1}{c|}{ LRH } \\
\hline RIVP & 0,4804089 & 0,0018000 & $-0,0068434$ & 0,0000115 \\
\hline ARNT & & 0,2209345 & 0,0074708 & 0,0107481 \\
\hline ADRS & & & 0,1016677 & 0,0114952 \\
\hline LRH & & & & 0,2725915 \\
\hline
\end{tabular}

Da bismo identificirali granicu učinkovitosti, prvo treba pronaći njene dvije glavne točke (Economist at Large, 2018):

- portfelj s minimalnom varijancom;

- portfelj s maksimalnim Sharpe-omjerom (tangencijalni portfelj).

Ovi izračuni napravljeni su pomoću Excel Solvera, a ovo je moguće riješiti i pomoću Lagrangeovih multiplikatora (Luenberg, 1998).

\section{Portfelj s minimalnom varijancom:}

\section{Očekivani prinos 0,404624855,}

\section{Standardna devijacija 0,231306829,}

\section{Sharpe omjer (nagib) 1,749299219}

Da bi ga se ostvarilo potrebni su sljedeći udjeli:
RIVP
0,117666799
ARNT
0,216202339
ADRS $\quad 0,499459798$
LRH $\quad 0,166672064$ 


\section{Tangencijalni portfeli:}

Očekivani prinos 0,432212856,

\section{Standardna devijacija 0,239061951,}

\section{Sharpe omjer (nagib) 1,807953351}

Da bi ga se ostvarilo potrebni su sljedeći udjeli:

$\begin{array}{ll}\text { RIVP } & 0,128857241 \\ \text { ARNT } & 0,317750019 \\ \text { ADRS } & 0,45400431 \\ \text { LRH } & 0,09938843\end{array}$

Sada treba pronaći nekoliko drugih točaka na granici efikasnosti. To utvrđujemo izračunom portfelja s najmanjom standardnom devijacijom za određenu razinu očekivanog prinosa (npr. postavimo očekivani prinos na $12 \%$, zatim na $14 \%$, zatim $16 \%$ itd. i pronađemo najmanju standardnu devijaciju za svaku opciju).

Pravac koji povezuje sve te "učinkovite" portfelje naziva se granicom učinkovitosti (efikasnosti). Izgled ovog pravca prikazan je na sljedećem Grafu (Slika 3).

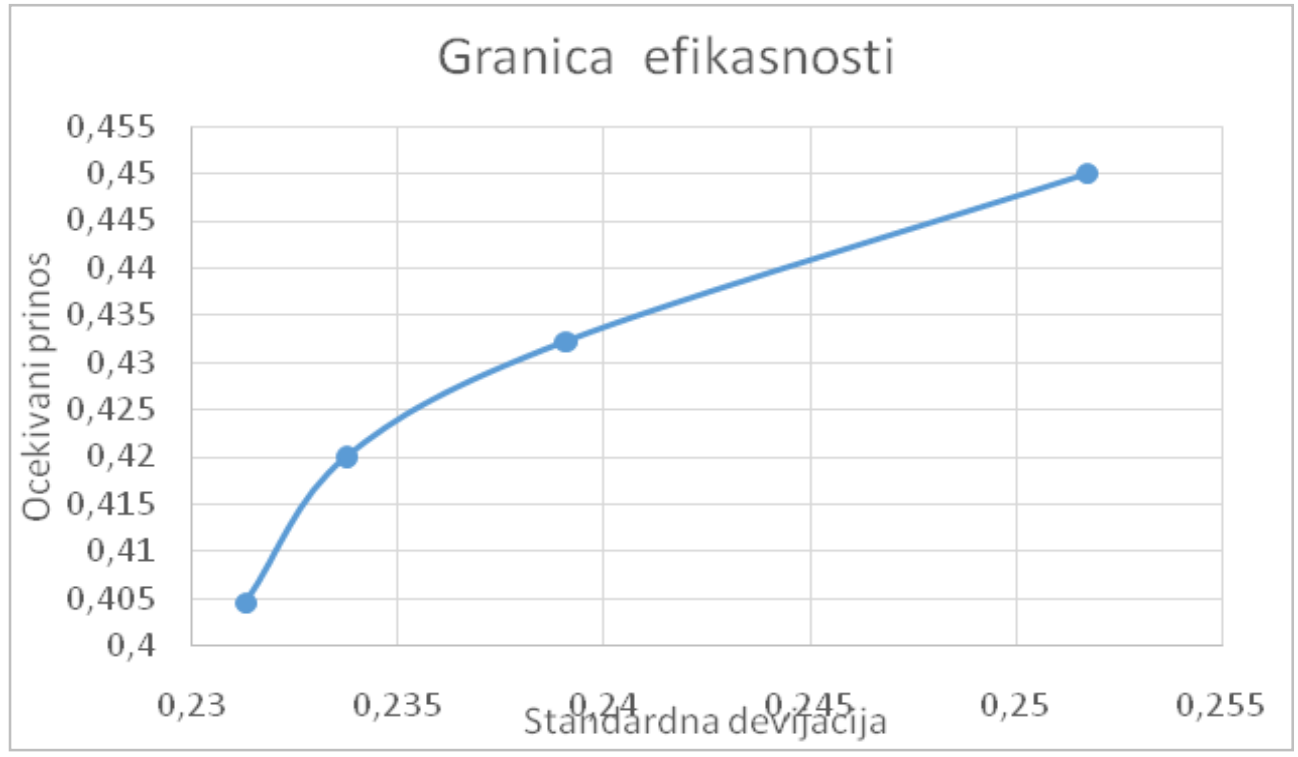

Slika 3. Granica učinkovitosti portfelja.

Figure 3. Efficient frontier of portfolio. 


\section{Zaključak}

Ovaj rad pokazuje način na koji racionalni i riziku neskloni investitori biraju svoje portfelje.

Odabir željenog portfelja ovisi o preferenciji rizika investitora definiranog standardnom devijacijom.

Preferencije rizika investitora rezultat su njihovih financijskih, psiholoških, dobnih i dr. razlika.

Vrlo plahi tj. riziku neskloni investitor odabire portfelj s minimalnom standardnom devijacijom na granici efikasnosti.

To je ovdje prikazano standardnom devijacijom od nešto više od 0,23 . Njoj odgovara očekivani prinos od 0,405 .

Što je investitor skloniji prihvatiti veći rizik to na granici efikasnosti pronalazi svoj idealni portfelj krećući se prema desnom gornjem uglu.

Najrizičniji portfelj je ovdje predstavljen standardnom devijacijom od oko 0,252 i očekivanim prinosom od 0,45 .

U niskorizičnom portfelju uključene su više dionice ADRS i LRH, a manje dionice RIVP i ARNT.

Suprotno, u visokorizičnom portfelju uključene su više dionice RIVP i ARNT, a manje dionice ADRS i LRH.

Ovdje je jasno pokazan osnovni princip financija da uz viši prinos nužno ide i veći rizik mjeren standardnom devijacijom.

\section{Literatura}

Berk, J., DeMarzo, P. (2016). Corporate Finance $4^{\text {th }}$ Edition. Stanford: Pearson.

Bodie, Z., Kane, A., Marcus A. J. (2006). Počela ulaganja. Zagreb: Mate.

Economist at Large (2018). Economist at Large: Chapter 4 - The Efficient Frontier. Posjećeno 01. 05. 2017. na mrežnoj stranici Economist at Large: http://economistatlarge.com/portfoliotheory/efficient-frontier.

Hirt, G. A., Danielsen, B. R., Block, S. B. (2009). Foundations of Financial management. Boston: McGraw-Hill-Irwin.

Luenberger, D. G. (1998). Investment Scienc. Oxford: Oxford Un. Press.

Markowitz, H. (1952). Portfolio Selection. Journal of Finance, 7 (1), 77-91. 
Z. Maričić, L. Maričić / Optimiziranje portfelja s različitim brojem imovine i različitim preferencijama rizika / Glasilo Future (2018) 1 (4) 17-30

Ross, S.A. \& Westerfield, R. W., Jordan, B. D. (1998). Fundamentals of corporate finance. New York: McGraw Hill Irwin.

Welch, I. (2008). Investments. Boston: Addison Wesley.

Welch, I. (2011). Corporate finance $4^{\text {th }}$ Edition - Early Preview. Boston: Addison Wesley.

Zagrebačka burza (2017). Posjećeno 01. 05. 2017. na mrežnoj stranici Zagrebačke burze: http://zse.hr.

Primljeno: 17. prosinca 2018. godine

Prihvaćeno: 31. prosinca 2018. godine
Received: December 17, 2018

Accepted: December 31, 2018 